の等分子混合物をエチルアルコールヌはイソフミルアルコールにてェステル化し，又（1）ステフリン酸とオ レイン酸との種々なる割合の混合物，(2) オレイン酸とラシリン酸との等分子混合物，(3) ステアリン酸とラ ウリン酸との等分子混合物をクリセリンにてェステル化したる場合に就て篮驗したるに、何れの場合に於てる

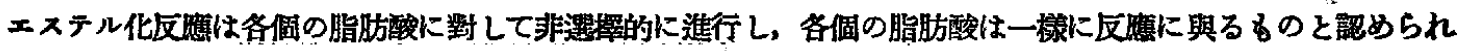
たり。

(東京工筆呵驗所第 2 部油脂研究窒)

\title{
36. ステアリン酸及オレイン䤇の混合物をエステル化して
}

\section{得らるよトリグリセライドの成分に就て}

\section{土屋知太郎 - 秋山五郎九}

ステテリン酸及オレイン酸の混合物をエステル化して得らるべきトッグセライドには(1)トッステアリン,

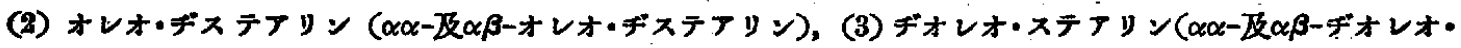
ステアリン), (4) トリオレインの 4 種類あり。

前報所载の研究によればステアリン酸及オレイン酸の等分子混合物とグリセシンとを加熱して得らる\トy グリセライドは化合脂肪酸としてステアリン酸度オレイン酸を等分子の㲅合に含有す。本報告は該クリセライ ドの成分に關する研究にして,歡グリセライドをヒルディッチ氏等(T. P. Hilditch and C. H. Lea, J. Chem. Soc., 1927, 3106; G. Collin and T. P. Hilditch, J. Soc. Chem. Ind., 1928, 47, 261 等) の過マンガン酸か リ酸化法によりて豦理し，分解生戌物を檢菜したる富驗結果を記載せるるのなり。

\section{1. 宾 驗之部}

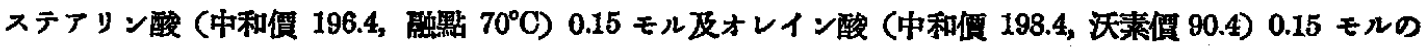

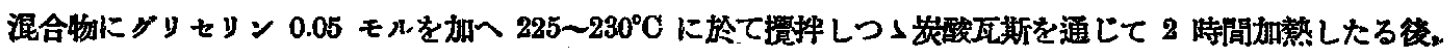

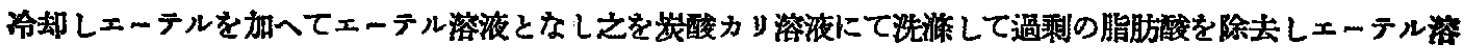
液よりエーテルを蒸溜して牫留物として踰化㵋 189.9, 沃菜價 42.1 なるグリセライドを收得せり。

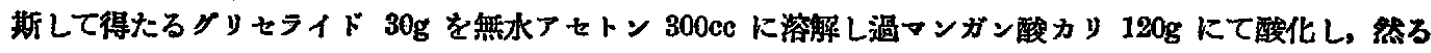

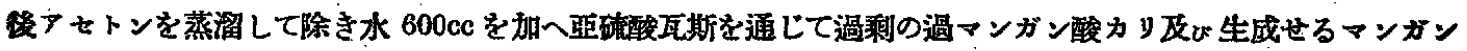
酸化物を還元し，夾にエーテル $2 l$ を用ひてグリセライドの酸化生咸物を抽出し，エーテル抽出液を少蜝の水 にて洗淡したる後，10\%炭酸カリ溶液を加一酸性物筫をカリ石龆となしてエーテル層と分離し、エーテル詹は

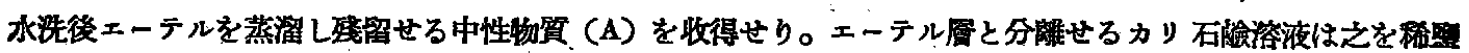
酸にて分解し遊猚せる酸性物貿をエーテルにて捕集しエーテル溶液を水洗後エーテルを蒸溜し，唒蒸氣蒸淄に

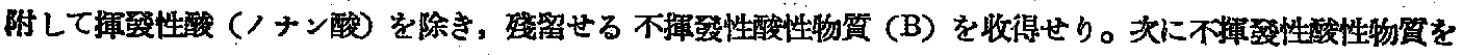

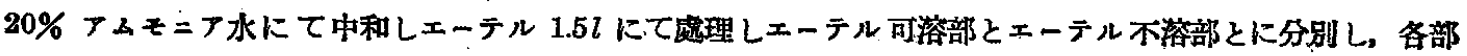

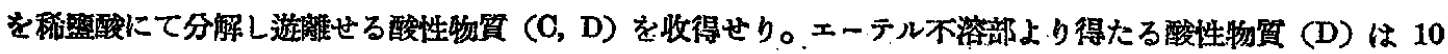

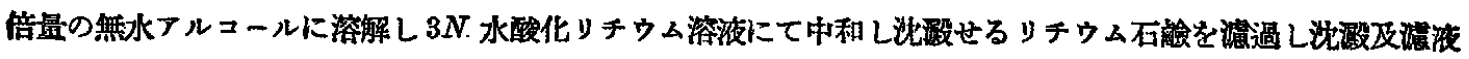
よりリチゥム石䠯を分解して酸性物賀 (E，F) を收得せり。以上の分別に体て 得たる各部の聂量次の如し。

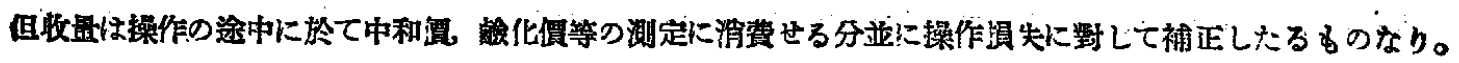



A, 中性物算 $6.4 \mathrm{~g}$
-
酸性物留
B. 不揮發性酸性物留 $18.1 \mathrm{~g}$

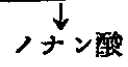
C. エーテル奇溶部の酸性物犋 $4.1 \mathrm{~g}$
アムモニア石螎をエーテルにて處理
E. アルコール可溶部の酸胜物質 $8.6 \mathrm{~g}$
D. エーテル不溶部の酸性物管 $14.0 \mathrm{~g}$

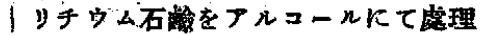
F.アルコール不楁部の酸性物犋 $5.4 \mathrm{~g}$

グリセライドがステフリン酸とオレイン酸とを等分子の割合に含有するものとせばグリセライド $30 \mathrm{~g}$ を過

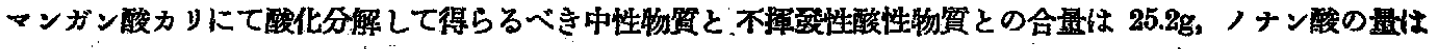
$8.0 \mathrm{~g}$ となるべきなり上上分別せる各部を检索すること知の如し。

A. 中性物貿 酸賈 8.6 , 沃素價 0.8 にして多少酸性物質を夾雜せるを以て之を炭酸カリ溶液にて洗涂したる

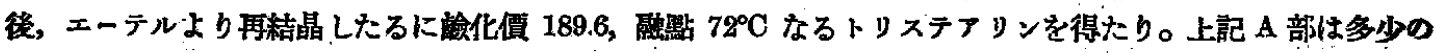

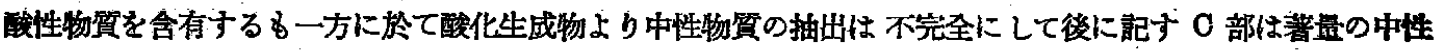

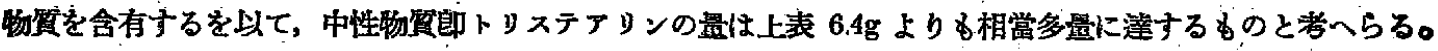
印合成せるクリセライド中のトリステテリンの遗は約 $20 \%$ 上上なること疑なし。

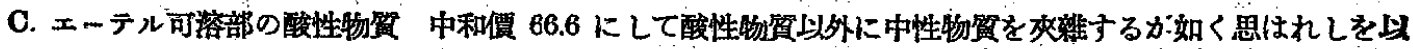

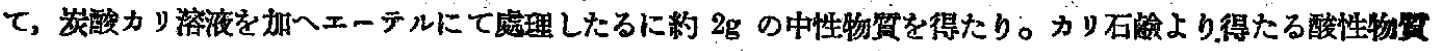
はリチウム石踰となしてアルュールにて㝚理し不溶部と可溶部とに分離し各部より唒性物質を收得して, 之を 更にエーテル,アセトン，石油エーテル等にて處理して次の各部に分別せり。

\section{C. エーテル可溶部の酸性物犋}

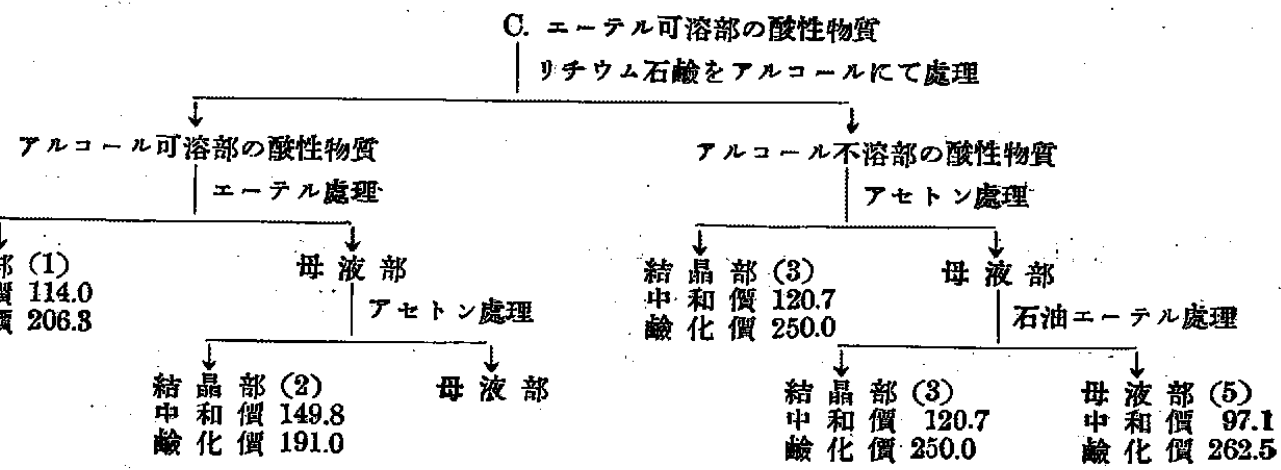

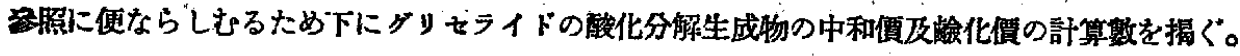

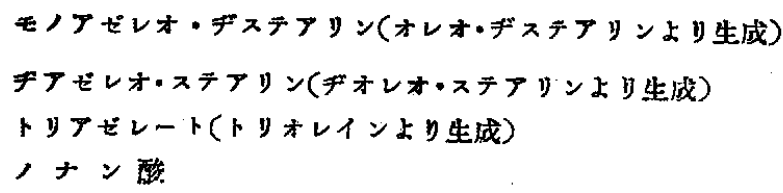




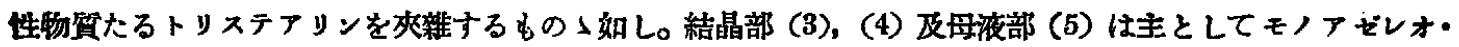

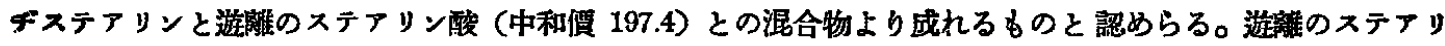

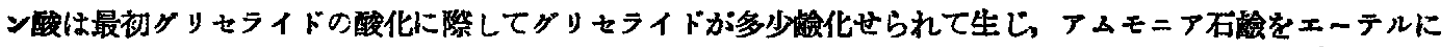
て處理せる際加水分解してエーデ中に入りしものと考へらる。

E. アルコール可溶部の酸性物留 熱晹アナセン，石油エーテルを用ひて光の如く分別せり。

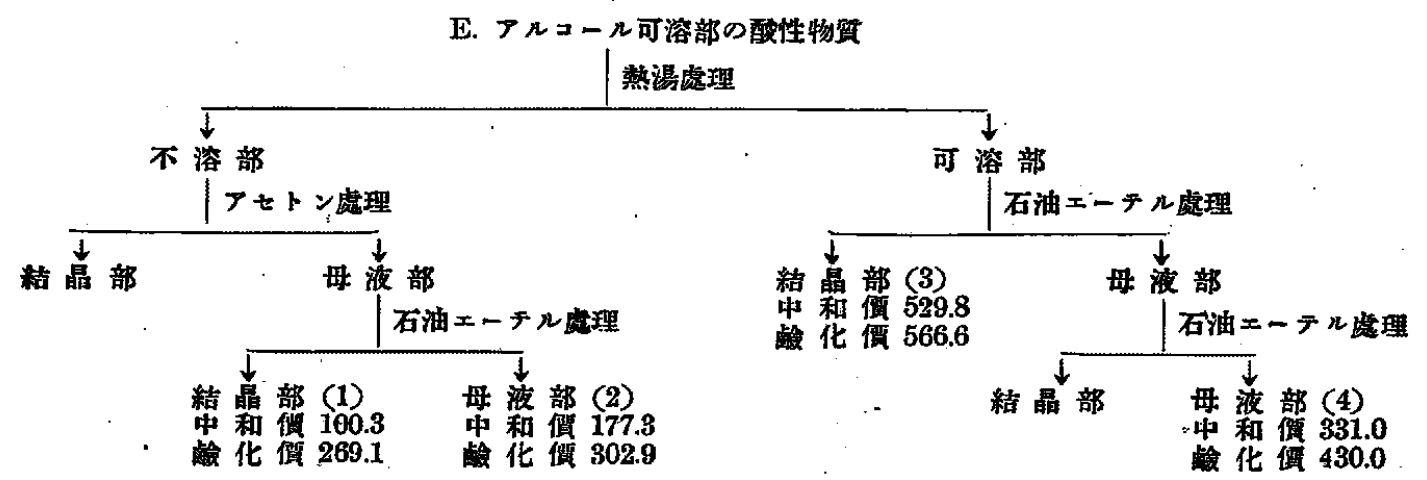

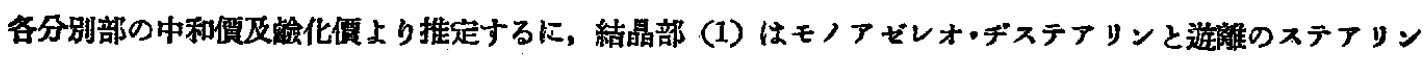

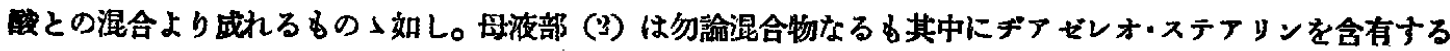
が如し。文結晶部（3）は加水分解によりて生じたるアゼライン酸を多螼に含有し，母液部 (4)は恐らくトリ

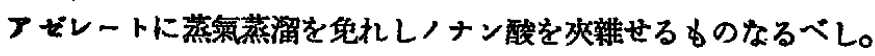

F. アルコール不签部の酸性物貿 アセトン, アルコール，石油エーテルを用ひて夷の㛎く分别せり。

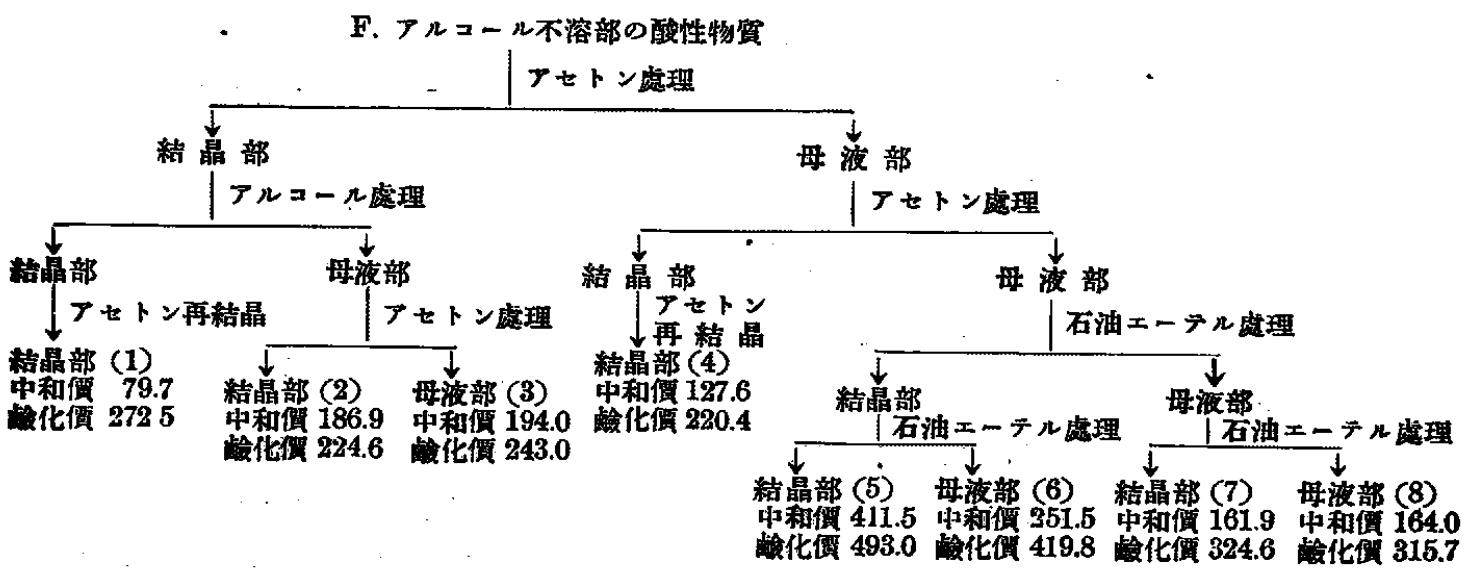

以上各分别部の弓ち結晶部 (1)はモノフゼレオ・デステアリンとステアリン酸との混合物より成り，(4)はス

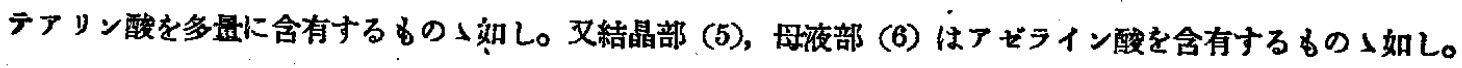
2. 總 括

ステテリン酸とオレイン酸との等分子混合物にダリセリンを作用せしめて得らる\グリセライドをアセトン 溶液に於て過マンガン酸カリを以て酸化し，酸化生成物を检柬したる結果によれば該グリセライドは歇 $20 \%$ 以上のトリステアリンを會有す。オレオ・デステアリン, ヂオレオ・ステアリン及トリオレインす勿踰生成すべ

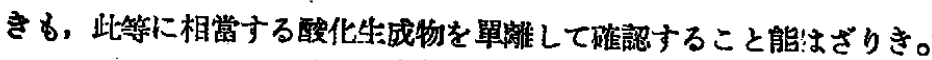

